\title{
Carolina Aznar Sánchez, Ester López Rosendo, María Jesús Aguilera Romojaro, alli. "El periódo persa en la llanura sur de Akko“"
}

\section{Astrid Nunn}

\author{
(2) OpenEdition \\ Journals \\ Édition électronique \\ URL : http://journals.openedition.org/abstractairanica/48365 \\ DOI : 10.4000/abstractairanica.48365 \\ ISBN : 1961-960X \\ ISSN : 1961-960X \\ Éditeur : \\ CNRS (UMR 7528 Mondes iraniens et indiens), Éditions de l'IFRI
}

\section{Référence électronique}

Astrid Nunn, «Carolina Aznar Sánchez, Ester López Rosendo, María Jesús Aguilera Romojaro, alli. "El periódo persa en la llanura sur de Akko" », Abstracta Iranica [En ligne], Volume 40-41 | 2019, document 33, mis en ligne le 15 juillet 2019, consulté le 27 avril 2021. URL : http://journals.openedition.org/ abstractairanica/48365 ; DOI : https://doi.org/10.4000/abstractairanica.48365

Ce document a été généré automatiquement le 27 avril 2021.

Tous droits réservés 


\title{
Carolina Aznar Sánchez, Ester López Rosendo, María Jesús Aguilera Romojaro, alli. "El periódo persa en la llanura sur de Akko"
}

\author{
Astrid Nunn
}

\section{RÉFÉRENCE}

Carolina Aznar Sánchez, Ester López Rosendo, María Jesús Aguilera Romojaro, alli. “El periódo persa en la llanura sur de Akko“, Aula Orientalis 35/1, 2017, p. 5-41

1 Ce projet espagnol est une prospection dans la plaine de Akko, au nord de Haifa. Son but: examiner la relation entres les Cananéens de la côte et ceux de l'intérieur du Bronze final au début de l'époque achéménide. Les A. ne retiennent pour cette contribution que les découvertes "annexes" de la période achéménide. Elles représentent 83 tessons de céramique, répartis sur les types connus de l'époque et une seule monnaie qui est un quart de sheqel de Tyr de 450-425 av. J.-C. Les A. relient leurs résultats à Tell Abu Hawam, ville contrôlée par Tyr selon le Pseudo-Scylax. En se basant sur cette description, Tell Abu Hawam devait encore être le port de Tell Keisan à l'époque achéménide. Tout en confirmant le savoir acquis, les résultats de la prospection y ajoutent quelques éléments supplémentaires. 


\section{AUTEURS}

\section{ASTRID NUNN}

Université de Munich 